\title{
Are Patients Diagnosed with Chronic Hepatitis B Aware of Their Disease?
}

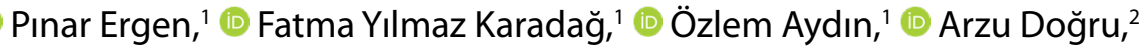 \\ Ayse Canan Üçışık, ${ }^{1}$ (i) Saadet Yazıcı, ${ }^{1}$ (i) Zuhal Aydan Sağlam, ${ }^{3}$ \\ Mustafa Haluk Vahaboglu'
}

'Department of Infectious Diseases and Clinical Microbiology, Medeniyet University Goztepe Training and Research Hospital, Istanbul, Turkey

${ }^{2}$ Department of Infectious Diseases and Clinical Microbiology, Tuzla State Hospital, Istanbul, Turkey

${ }^{3}$ Department of Family Medicine, Istanbul Training and Research Hospital, Istanbul, Turkey

\section{ABSTRACT}

Objectives: This study aims to determine the level of knowledge of patients being followed up with a diagnosis of chronic hepatitis B Infection about the disease, route of transmission, prevention and treatment.

Methods: A cross-sectional survey was conducted between June-December 2016. The survey consisted of questions about demographic information, general information about the disease, routes of transmission, prevention, treatment and patient follow-up.

Results: The questionnaire was administered to 500 patients. The mean age of the patients was $42.2 \pm 12.9$ years, 319 (63.8\%) were male. In this study, 141 (28.2\%) of the patients said that hepatitis B was not an infectious disease. The level of knowledge about the name of the disease, infectiousness and its complications was significantly high in patients with a high education level and in patients who were diagnosed with hepatitis B for more than five years. While 214 (98.7\%) patients with high education level knew the name of the disease and 191 (88.0\%) patients knew virus' infectiousness and its complications. Three hundred twenty-one (97.6\%) patients with hepatitis B for more than five years knew the name of the disease and $278(84.5 \%)$ patients knew the virus' infectiousness and its complications.

Conclusion: Hepatitis B infection stil remains a critical health problem for both the patient and his environment. Increasing awareness of patients about their diseases will decrease the spread of infection and control the complications that may arise in the future due to hepatitis $B$.

Keywords: Awareness, hepatitis B, knowledge

\section{INTRODUCTION}

Hepatitis B virus (HBV) infection is a worldwide public health problem, with an estimated 350 million HBV-infected people and approximately 600.000 deaths from HBV annually. ${ }^{[1,2]}$ The number of cases infected with HBV continues to increase, especially in sub-Saharan Africa, Tropical and Central Latin America, Southeast Asia and Eastern Europe. Despite the massive vaccination programs, the disease cannot be eradicated. ${ }^{[2-4]}$ The prevalence of HBV surface antigen positivity in Turkey varies by region, with an average of $4 \%$. Turkey is a country of intermediate endemicity. ${ }^{[5,6]}$

With the coverage of the hepatitis B vaccine in the national vaccination program in 1998, the number of adolescents infected with HBV has been on the decline. However, the overall rate 
of HBV seroprevalence mains high in adults, requiring more rigorous measures targeted at this group. ${ }^{[7]}$

Patients infected with HBV compose a great majority of those presenting to infectious diseases and clinical microbiology outpatient clinics. Because of the likelihood of HBV infection to become chronic, it is essential that patients be monitored regularly life-long and, if necessary, receive antiviral agents to suppress viral load. ${ }^{[1]}$

In a study conducted in our country, the findings showed that $60 \%$ of the patients diagnosed with hepatitis B had information about disease and transmission routes, and $72 \%$ of them had information about complications. Similar results were found in studies abroad..$^{[8-10]}$

The present study aims to evaluate the knowledge of patients with hepatitis $B$ about the passageway, prevention and treatment of their diseases, to eliminate the deficiency information and thus contribute to reducing the spread of the infection.

\section{METHOD}

In this cross-sectional study, the questionnaire was prepared, including items about demographic information, duration of disease, overall information about the disease, routes of transmission and prevention methods. The questionnaire was then administered to 500 patients who presented to the Infectious Diseases and Clinical Microbiology outpatient clinic of Medeniyet University Göztepe Training and Research Hospital and received a diagnosis of Chronic Hepatitis B Infection (CHBI) between June 1-December 31, 2016. Only patients who volunteered to respond to the questionnaire were included in this study. Exclusion criteria were those under the age of 18 years and non-volunteers.

Data were processed using SPSS IBM 22.0 (SPSS Inc., Chicago II) software. Distribution of data was evaluated usingthe Kolmogorov-Smirnov test. Descriptive variables were expressed as frequency, percentages, mean, standard deviation and abnormally distributed variables as median (minimum-maximum). Comparisons were made using the Chi-squared test and Fischer's exact test. A p-value of less than 0.05 was considered statistically significant.

\section{RESULTS}

Five hundred patients participated to the study. The mean age of the patients was $42.2 \pm 12.9$ years. The median duration of the disease was $108.0(1.0-845.0)$ months. In this study, 181 (36.2\%) patients were female and 319 (63.8\%) patients were male. The majority of the patients, 357(71.4\%) were regularly followed up, and 199 (39.8\%) were receiving treatment. Table 1 shows general characteristics of the patients with hepatitis $\mathrm{B}$. The diagnosis of $\mathrm{CHBI}$ was made to
Table 1. General characteristics of the patients with hepatitis B

Gender

Female

181 (36.2)

Male

319 (63.8)

Age groups

18-40 years

$237(47.4)$

41 years of age and older

263 (52.6)

Level of education

Illiterate

32 (6.4)

Primary

182 (36.4)

Secondary

69 (13.8)

High school

$115(23.0)$

College

102 (20.4)

Come to regular control

Yes

357 (71.4)

No

143 (28.6)

Duration of the disease

$\leq 60$ months

171 (34.2)

$>60$ months

329 (65.8)

Taking medication

Yes

199 (39.8)

No

$301(60.2)$

199 (39.8\%) patients who admitted to the hospital for any reason by chance. Table 2 shows the occasions on which the participants were notified to have been infected with HBV. Patients were asked various questions about Hepatitis B. The results obtained in this study showed that 180 (36.0\%) of the patients replied "No" or "I don't know" to the question of whether the disease was contagious. The distribution of the

Table 2. The occasions on which the participants were

notified about the diagnosis of $\mathrm{CHBI}$

The occasions of being notified n (\%)

Incidentally (during an examination) 75 (15.0)

During blood donation $64(12.8)$

Preoperative screening

63 (12.6)

Family screening

$37(7.4)$

Screening during pregnancy

$27(5.4)$

Screening during military service

26 (5.2)

Premarital screening

9 (1.8)

Investigation into the etiology of

$199(39.8)$

elevated liver enzymes

CHBI: Chronic Hepatitis B Infection. 
answers to the questions about the name, treatment, prognosis and infectiousness of the disease is shown in Table 3.

Patients were asked questions about hepatitis B transmission routes and prevention. Table 4 shows the patients' responses to questions about the transmission and prevention of HBV. Their knowledge about blood-borne transmission, sexual transmission, and vertical transmission from mother to baby were questioned. The patients' responses to transmission routes are shown in Table 5.

While 214 (98.6\%) of the patients with high education level (high school and above education level) knew the name of the disease, 191 (97.0\%) of them knew of the infectiousness and complications. For patients who had the hepatitis B for more than five years, 321 (97.6\%) of them knew the name of the disease, 278 (97.5\%) of them knew about infectiousness and complication. While 313 (97.3\%) patients who came for regular control knew that they could be protected with vaccination, $134(91.8 \%)$ patients who had been diagnosed with hepatitis $B$ for more than five years knew that they could be protected with vaccination. The findings indicated that 175 (96.7\%) female and 298 (93.4\%) male knew the name of their disease. While 162 (96.4\%) female and 268 (92.7\%) male knew that they could be protected with vaccination, complications were known to 153 (98.1\%) female and 243 (95.3\%) male. There were no age and sex-related differences in the level of knowledge about the name of the disease, prevention through vaccination, as well as the complications. Table 6 presents information about the patients' knowledge of the disease, disease complications and whether it is a preventable disease.

Table 3. Distribution of the responses to overall information about the disease

\begin{tabular}{|c|c|c|c|}
\hline & No & Yes & Do not know \\
\hline Is your disease infectious? & $141(28.2)$ & $320(64.0)$ & $39(7.8)$ \\
\hline Can your disease cause cirrhosis or liver cancer in the future? & $15(3.0)$ & $396(79.0)$ & $89(18.0)$ \\
\hline Did you have a family screening for hepatitis $B$ ? & $65(13.0)$ & $435(87.0)$ & $0(0.0)$ \\
\hline
\end{tabular}

\section{Table 4. Questions about transmission and prevention of HBV}

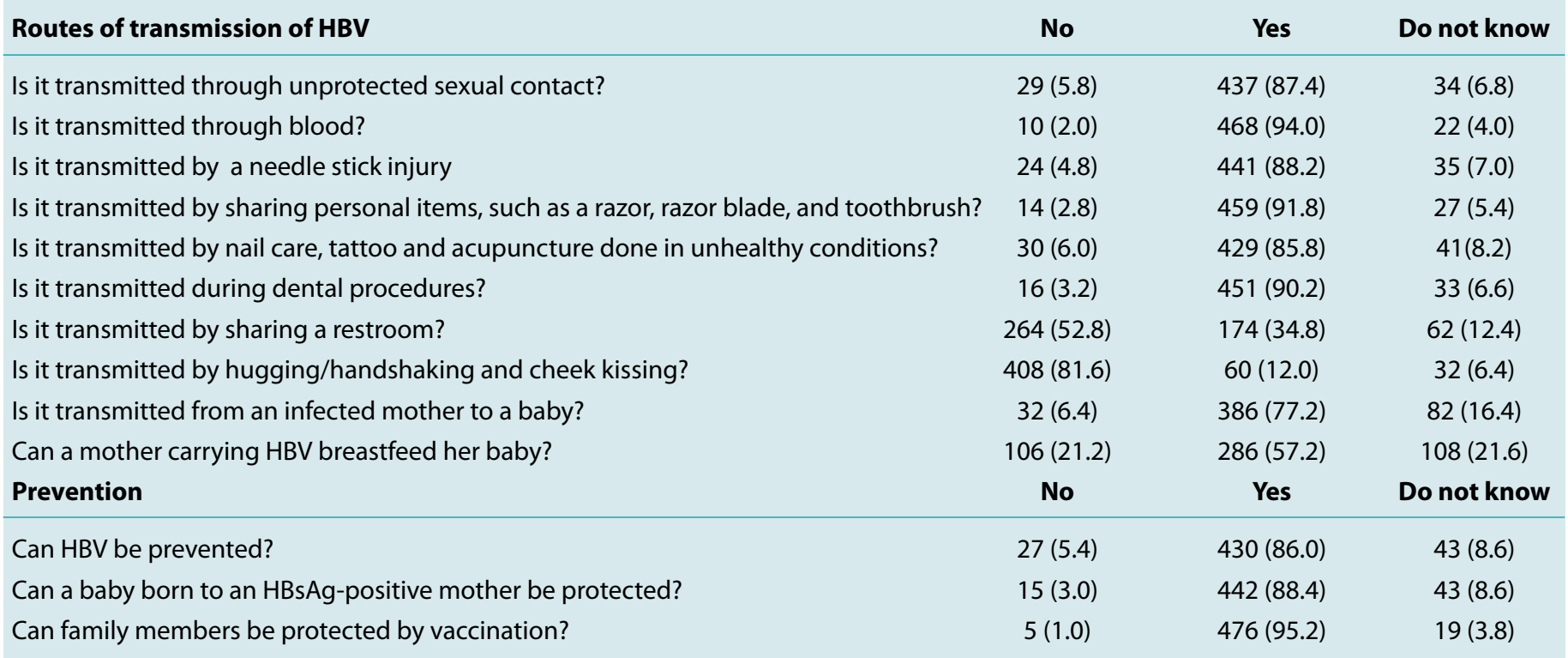




\section{Table 5. General characteristics of the patients with hepatitis B and knowledge of ways of transmission}

\begin{tabular}{|c|c|c|c|c|c|c|c|c|c|}
\hline & \multicolumn{3}{|c|}{ Through blood } & \multicolumn{3}{|c|}{ Through sexual contact } & \multicolumn{3}{|c|}{ From mother to baby } \\
\hline \multicolumn{10}{|l|}{ Gender } \\
\hline Female & $171(94.5)$ & $10(5.5)$ & 0.276 & $162(89.5)$ & $19(10.5)$ & 0.561 & $147(81.2)$ & $34(18.8)$ & 0.042 \\
\hline Male & $297(93.1)$ & $22(6.9)$ & & $275(86.2)$ & $44(13.8)$ & & $239(74.9)$ & $80(25.1)$ & \\
\hline \multicolumn{10}{|l|}{ Age groups } \\
\hline$\geq 41$ years & $244(92.8)$ & $19(7.2)$ & & $222(84.4)$ & $41(15.6)$ & & $186(70.7)$ & $77(29.3)$ & \\
\hline \multicolumn{10}{|l|}{ Education } \\
\hline Illiterate & $24(75.0)$ & $8(25.0)$ & $<0.001$ & $23(71.9)$ & $9(28.1)$ & $<0.001$ & $19(59.4)$ & $13(40.6)$ & 0.007 \\
\hline Primary & $166(91.2)$ & $16(8.8)$ & & $143(78.6)$ & $39(21.4)$ & & $132(72.5)$ & $50(27.5)$ & \\
\hline Secondary & $61(88.4)$ & $8(11.6)$ & & $58(84.1)$ & $11(15.9)$ & & $53(76.8)$ & $16(23.2)$ & \\
\hline Yes & 335 (93.8) & $22(6.2)$ & 0.189 & $313(87.7)$ & $44(12.3)$ & 0.028 & 277 (77.6) & $80(22.4)$ & 0.036 \\
\hline No & $133(93.0)$ & $10(7.0)$ & & $124(86.7)$ & $19(13.3)$ & & $109(76.2)$ & $34(23.8)$ & \\
\hline \multicolumn{10}{|c|}{ Duration of the disease } \\
\hline$\leq 5$ years & $155(90.6)$ & $16(9.4)$ & 0.027 & $140(81.9)$ & $31(18.1)$ & 0.001 & $126(73.7)$ & $45(26.3)$ & 0.036 \\
\hline$>5$ years & $313(95.1)$ & $16(4.9)$ & & $297(90.3)$ & $32(9.7)$ & & $260(79.0)$ & $69(21.0)$ & \\
\hline
\end{tabular}

Chi-square test and Fischer's exact test.

Data were given as $\mathrm{n}(\%)$.

Table 6. Knowledge levels of patients about disease name, complications and prevention

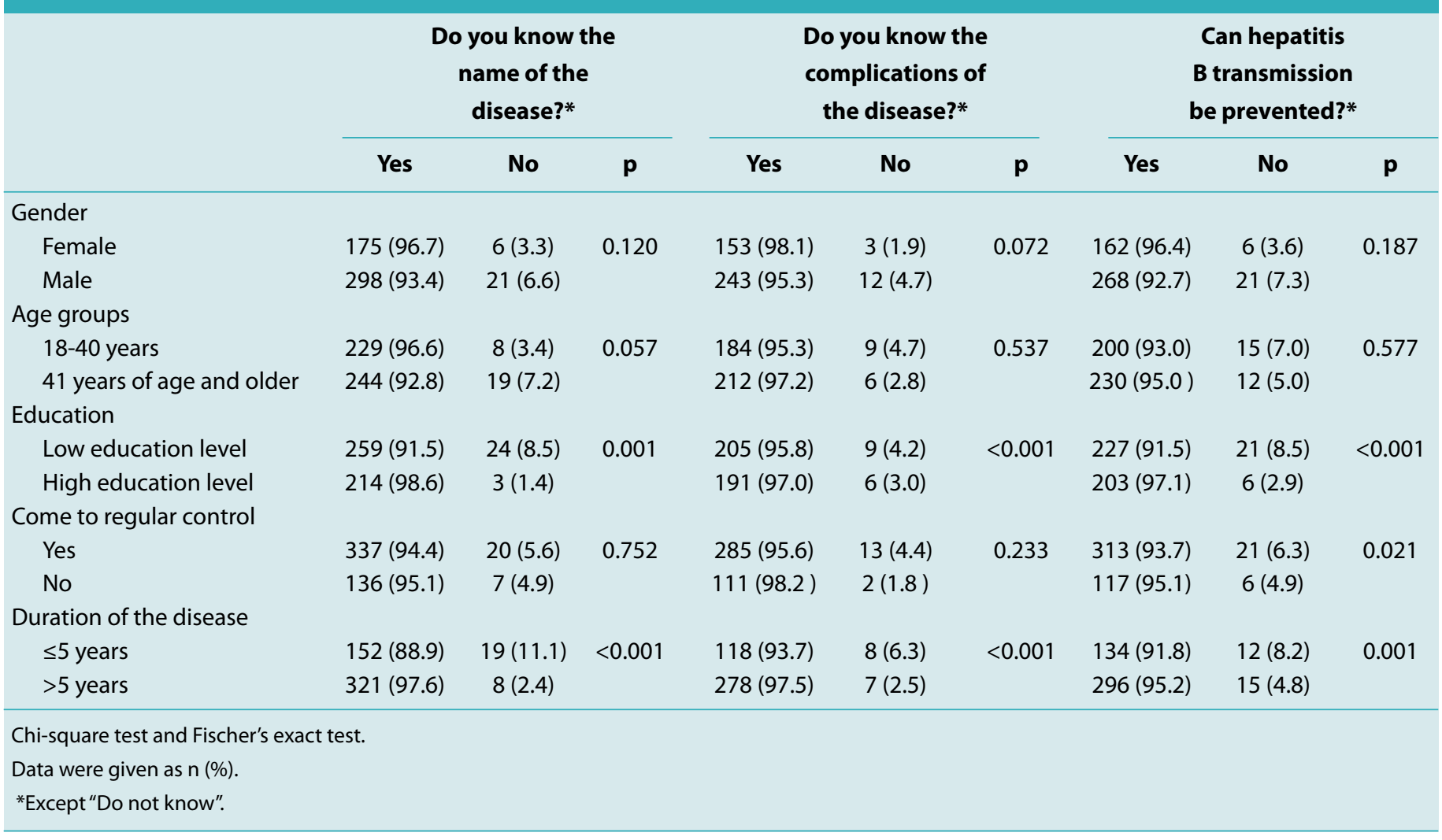




\section{DISCUSSION}

HBV infection is a global public health problem. Preventive medicine should be practiced reducing the prevalence of HBV infection. Turkey Viral Hepatitis Prevention and Control Program by the Republic of Turkey Ministry of Health (2018-2023) has targeted at early diagnosis and treatment, as well as raising awareness of the entire community, and a national plan has been prepared. ${ }^{[1]]}$ Raising public awareness about the issue is of vital importance. To increase awareness, the patient and their immediate environment, as well as healthy individuals, should also be informed about the causative agent, transmission routes, and complications of the disease and who is at risk.

The level of knowledge about hepatitis $B$ was found to be significantly high in patients with a high education level and in patients who were diagnosed with HBV for more than five years. People with a high education level are considered that they search and question more about their disease and gain access to the knowledge more easily through the internet. Having knowledge about the disease for a long time means more frequent presentation to an outpatient clinic and seeing more physicians and talking more about the condition. Individuals who have knowledge about their disease for a long time and who have a high level of education have increased awareness about their disease.

In this study, patients whose disease duration was for more than five years and whose education level was higher were aware that they were contagious. The best way to prevent the spread of HBV infection is to have the knowledge of being a contagious patient and to take the necessary precautions for the people around. People who know to have a vaccine-preventable disease act accordingly. In their survey, Gürakar et al. reported that $60 \%$ of the participants had knowledge about the disease and its transmission routes and that patients with high education level got their family members more vaccinated. ${ }^{[8]}$

Our survey has shown that the level of the knowledge about the disease did not differ significantly concerning age and gender, but the level of education does differ considerably. The lower the level of education is, the lower the level of knowledge regarding the disease is. Ganczak et al., in a survey, including 420 people in Poland, have reported that hepatitis $B$ infection continues to be a threat to public health and that education should be provided primarily aiming at people who have a low education level..$^{[12]}$ Another study in Australia found similar results and pointed out the need for targeting patients with a low education level. ${ }^{[13]}$ The study conducted by Güner et al. that evaluated the knowledge levels of the patients revealed that the knowledge levels were insufficient regardless of their education levels. Attention has been drawn that giving much weight to providing the patients with knowledge about their disease will be beneficial both in the follow-up and treatment of their disease and in coping with the challenges in social life. ${ }^{[14]}$

We found that $71.4 \%$ of our patients adhered to outpatient follow-up visits. This low rate can be attributed to that patients still had difficulty in accepting their illnesses and considered their illnesses to be concealed due to the fear of either social rejection or being dismissed from work, both of which prevented them from asking for permission for control visits. Unlike the patients who adhered to followups, these patients did not have much knowledge about their disease and its consequences. If adherence to followup visits is accomplished, the patients may obtain accurate and adequate knowledge about $\mathrm{CHBI}$ to get rid of their worries and they will no longer be a risk for them.

It seems that not only in schools and hospitals but also through written and visual media, education must be imparted to the whole society and campaigns should be launched. The study carried out by Gürakar et al. suggested that mass education strategies for raising awareness about hepatitis $B$ and prevention its spread should be promoted. ${ }^{[8]}$ Our results are consistent with those obtained by most studies conducted on patients with $\mathrm{CHBI}$ in other countries. In their survey conducted among 390 patients with $\mathrm{CHBI}$ in Pakistan, Haq et al. reported that patients had little basic knowledge of infection control and its management, which might cause the spread of infection, requiring an awareness campaign. ${ }^{[9]}$ In the study of 19 centers in India, the knowledge levels of the patients were evaluated with a scoring system. The survey results emphasized that patients infected hepatitis B had little basic knowledge about the disease and its transmission routes and that more education was warranted. ${ }^{[10]}$

We think that some patients either ignore their illnesses due to the fear of being isolated from society or conceal their condition because of the challenges encountered in social life and job applications. In a study evaluating the levels of knowledge and stigma about hepatitis B infection among infected and non-infected people in China, $45 \%$ of healthy individuals were found to be anxious about having a close contact with sick people and $39 \%$ felt discomfort about sharing their food with infected people. Of these individuals, 58\% were of the opinion that patients should not be allowed to work in restaurants and $44 \%$ said that patients should not be allowed to work in child care. Some patients stated that they considered themselves to be eco- 
nomically a burden on their families and experienced employment-associated challenges (missing the opportunity for employment due to the obligation of an HBV test before application). In conclusion, the study in China where the disease has an increased prevalence revealed that despite limited knowledge, there was both social and stigmatization. ${ }^{[15]}$ A study from the United States performed among Asian-Americans, one-tenth of whom were infected with HBV, found that they lacked basic knowledge about HBV infection, its transmission routes and its prevention. The patients were found to be worried about developing cancer and transmitting the disease to their loved ones and being stigmatized, and it was concluded that more education should be imparted to infected people. ${ }^{[16]}$

A study from Iran, where an estimated 1.5-2.5 million HBVinfected people live, emphasized that the patients concealed their illness because of fear of stigmatization and that implementing health education programs about hepatitis B was warranted, especially considering the potential impact of mass media campaigns. ${ }^{[17]}$ A quality-of-life study among patients infected with HBV in Turkey reported that patients displayed higher stigma scores after the diagnosis, particularly in the long-term, while other domain scores remained unremarkable. ${ }^{[18]}$ According to the data from the World Health Organization, an estimated 60 million people with $\mathrm{CHBI}$ live in Africa and the prevalence is still high despite vaccination programs. A survey on the knowledge and awareness conducted among 758 people in Nigeria has shown that there is an urgent need for intervention aimed to raise awareness about the presence of the HBV infection and vaccination. ${ }^{[19,20]}$

All these studies address the lack of knowledge as the source of the misconception of both patients and society about the disease. ${ }^{[15,16]}$ In 2015, the leading viral hepatitis specialists from Bangladesh, India, Indonesia, Malaysia, Pakistan, the Philippines and Thailand, the Coalition to Eradicate Viral Hepatitis in the Asia Pacific (CEVHAP), convened and discussed the challenges in coping with the disease. In all of these countries, the significant systemic, cultural and financial barriers to the eradication of hepatitis have been reported to continue. The most commonly encountered problems were demonstrated to include a shortage of reliable epidemiological data, little public awareness about transmission and risk factors, high transmission rates with infected blood products, difficulty in reaching intravenous drug users, stigmatization and isolation of infected persons, financial barriers to treatment and prevention and it has been reported that cross-sector collaboration is critical to take urgent action. It appears that the only solution is to start a public education movement. It has been revealed that only local and regional efforts will not suffice, with the global strategies being developed. ${ }^{[21]}$ The World Health Organization's 2016-2021 Global Health Sector Strategy on Viral Hepatitis provides a firm framework for governments to develop local strategies for viral hepatitis and targets to eliminate viral hepatitis as a public health threat by 2030 . ${ }^{[22]}$ At the International Viral Hepatitis Elimination Meeting (IVHEM) held in Amsterdam in December 2018, specialist clinicians, virologists and public health professionals discussed the successful and incomplete parts of existing elimination programs in many countries and concluded that community participation was warranted for elimination. ${ }^{[23]}$ In Turkey, a strategy plan to combat viral hepatitis has been prepared, and it has been pointed out that all individuals, academics, primarily the ministry of health as well as individuals in public and private organizations, are responsible for the fulfillment of these plans. ${ }^{[8]}$

Our questionnaire was conducted on a voluntary basis, and the limitation of the study is that it does not include all patients with hepatitis $B$ diagnosis who applied to the outpatient clinic.

\section{CONCLUSION}

ICHBI remains a critical health problem for both the patient and their environment. There is a vital responsibility for all physicians in the prevention of viral hepatitis in Turkey, and at this stage, a significant task falls to family physicians. Patients should be made aware of the issues, such as transmission, prevention and vaccination of seronegative family members by family physicians. In this way, knowledge and awareness will increase in patients, and disease and related health problems will decrease. Educating the entire community about the disease, as well as patients, will help control hepatitis $B$ in the future.

\section{Disclosures}

Peer-review: Externally peer-reviewed.

Conflict of Interest: None declared.

Ethics Committee Approval: This study was approved by the Institutional Review Board of Medeniyet University Göztepe Training and Research Hospital (Approval date: 28.06.2016, Approval number: 2016/0152).

Authorship Contributions: Concept - P.E., F.Y.K., Ö.A., A.D., A.C.Ü., S.Y., Z.A.S., M.H.V.; Design - P.E., F.Y.K., Ö.A.; Supervision - P.E., F.Y.K., Ö.A.; Materials - P.E., F.Y.K., Ö.A., A.D., A.C.Ü., S.Y.; Data collection \&/ or processing - P.E., F.Y.K., Ö.A., A.D., A.C.Ü., S.Y.; Analysis and/or interpretation - P.E., F.Y.K., Ö.A., A.D., A.C.Ü., S.Y., Z.A.S., M.H.V.; Literature search - P.E., F.Y.K.; Writing - P.E., F.Y.K., Ö.A.; Critical review - P.E., F.Y.K., Ö.A., A.D., A.C.Ü., S.Y., Z.A.S., M.H.V. 


\section{REFERENCES}

1. Lavanchy D. Hepatitis B virus epidemiology, disease burden, treatment, and current and emerging prevention and control measures. J Viral Hepat. 2004 Mar;11(2):97-107. [CrossRef]

2. Goldstein ST, Zhou F, Hadler SC, Bell BP, Mast EE, Margolis HS. A mathematical model to estimate global hepatitis B disease burden and vaccination impact. Int J Epidemiol. 2005 Dec;34(6):1329-39. [CrossRef]

3. Ott JJ, Stevens GA, Groeger J, Wiersma ST. Global epidemiology of hepatitis $B$ virus infection: new estimates of age-specific HBsAg seroprevalence and endemicity. Vaccine. 2012 Mar 9;30(12):2212-9. [CrossRef]

4. Maddrey WC. Hepatitis B: an important public health issue. J Med Virol. 2000 Jul;61(3):362-6. [CrossRef]

5. Schweitzer A, Horn J, Mikolajczyk RT, Krause G, Ott JJ. Estimations of worldwide prevalence of chronic hepatitis $B$ virus infection: a systematic review of data published between 1965 and 2013. Lancet. 2015 Oct 17;386(10003):1546-55. [CrossRef]

6. Toy M, Önder FO, Wörmann T, Bozdayi AM, Schalm SW, Borsboom GJ, van Rosmalen J, Richardus JH, Yurdaydin C. Ageand region-specific hepatitis $B$ prevalence in Turkey estimated using generalized linear mixed models: a systematic review. BMC Infect Dis. 2011 Dec 12;11:337. [CrossRef]

7. Ay $P$, Torunoğlu MA, Com S, Çipil Z, Mollahaliloğlu S, Erkoç Y, et al. Trends of hepatitis B notification rates in Turkey, 1990 to 2012 separator commenting unavailable. Euro Surveill 2013;18(47):pii=20636. [CrossRef]

8. Gürakar M, Malik M, Keskin O, Idilman R. Public awareness of hepatitis $B$ infection in Turkey as a model of universal effectiveness in health care policy. Turk J Gastroenterol. 2014 Jun;25(3):304-8. [CrossRef]

9. ul Haq N, Hassali MA, Shafie AA, Saleem F, Farooqui M, Haseeb A et al. A cross-sectional assessment of knowledge, attitude and practice among Hepatitis-B patients in Quetta, Pakistan. BMC Public Health 2013;13:448. [CrossRef]

10. Tamayo A, Shah SR, Bhatia S, Chowdhury A, Rao PN, Dinh P, Knox SJ, Gaggar A, Subramanian GM, Mohan VG, Sood A, Mehta R, Sarin SK. Correlates of disease-specific knowledge among patients with chronic hepatitis $B$ or hepatitis $C$ infection in India. Hepatol Int. $2016 \mathrm{Nov} ; 10(6): 988-995$. [CrossRef]

11. Türkiye Viral Hepatit Önleme ve Kontrol Programı, Sağlık Bakanlığı Yayın No: 1102, Ankara , 2018. Available at: https:// hsgm.saglik.gov.tr/depo/birimler/Bulasici-hastaliklar-db/ duyurular/Turkiye_Viral_Hepatit_Onleme_ve_Kontrol_Programi/Turkiye_Viral_Hepatit_Onleme_ve_Kontrol_Programi_ TR.pdf. Accessed Oct 30, 2020.

12. Ganczak M, Dmytrzyk-Daniłów G, Korzeń M, Drozd-Dąbrowska
M, Szych Z. Prevalence of HBV Infection and Knowledge of Hepatitis B Among Patients Attending Primary Care Clinics in Poland. J Community Health. 2016 Jun;41(3):635-44. [CrossRef]

13. Hajarizadeh B, Wallace J, Richmond J, Ngo N, Enright C. Hepatitis B knowledge and associated factors among people with chronic hepatitis B. Aust N Z J Public Health. 2015 Dec;39(6):563-8. [CrossRef]

14. Güner R, Kaya A, Hasanoğlu İ, Keske Ş, Güven T, Yılmaz GR, Taşyaran MA. Hepatit B Virüsü İle Enfekte Hastaların Hastalık Hakkında Bilgi Düzeylerinin Değerlendirilmesi. Viral Hepatit Dergisi 2012; 18(1): 29-33. [CrossRef]

15. Huang J, Guan ML, Balch J, Wu E, Rao H, Lin A, Wei L, Lok AS. Survey of hepatitis $B$ knowledge and stigma among chronically infected patients and uninfected persons in Beijing, China. Liver Int. 2016 Nov;36(11):1595-1603. [CrossRef]

16. Carabez RM, Swanner JA, Yoo GJ, Ho M. Knowledge and fears among Asian Americans chronically infected with hepatitis $B$. J Cancer Educ. 2014 Sep;29(3):522-8. [CrossRef]

17. Valizadeh L, Zamanzadeh V, Bayani M, Zabihi A. The social stigma experience in patients with hepatitis B infection. Gastroenterol Nursing Center 2017;40(2):143-150. [CrossRef]

18. Karacaer Z, Cakir B, Erdem H, Ugurlu K, Durmus G, Ince NK et al. Quality of life and related factors among chronic hepatitis B-infected patients: a multi-center study, Turkey. Health Quality of Life Outcomes. $2016 ; 14(1): 153$. [CrossRef]

19. WHO. Global Hepatitis Report, 2017. Available at: https:// www.who.int/hepatitis/publications/global-hepatitis-report2017/en/. Accessed April, 2017.

20. Eni AO, Soluade MG, Oshamika OO, Efekemo OP, Igwe TT, OnileEre OA. Knowledge and Awareness of Hepatitis B Virus Infection in Nigeria. Ann Glob Health. 2019 Apr 11;85(1):56. [CrossRef]

21. WHO. Global Health Sector Strategy On Viral Hepatitis 20162021 Towards Ending Viral Hepatitis. Available at: https:// www.who.int/hepatitis/strategy2016-2021/ghss-hep/en/. Accessed June, 2016.

22. Wait S, Kell E, Hamid S, Muljono DH, Sollano J, Mohamed R, Shah S, Mamun-Al-Mahtab, Abbas Z, Johnston J, Tanwandee T, Wallace J. Hepatitis B and hepatitis $C$ in southeast and southern Asia: challenges for governments. Lancet Gastroenterol Hepatol. 2016 Nov;1(3):248-255. [CrossRef]

23. Popping $S$, Bade $D$, Boucher $C$, van der Valk $M$, El-Sayed $M$, Sigurour O, Sypsa V, Morgan T, Gamkrelidze A, Mukabatsinda C, Deuffic-Burban S, Ninburg M, Feld J, Hellard M, Ward J. The global campaign to eliminate HBV and HCV infection: International Viral Hepatitis Elimination Meeting and core indicators for development towards the 2030 elimination goals. J Virus Erad. 2019 Jan 1;5(1):60-66. [CrossRef] 